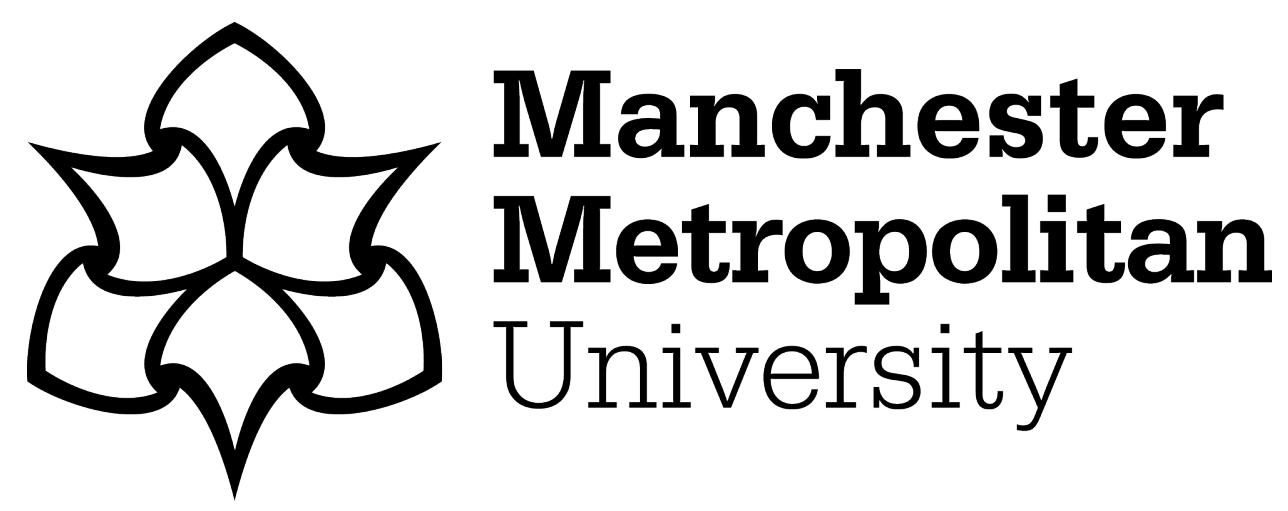

Stobart, Jon (2018) Housekeeper, correspondent and confidante: The undertold story of Mrs Hayes of Charlecote Park, 1744-73. Family and Community History, 21 (2). pp. 96-111. ISSN 1463-1180

Downloaded from: https://e-space.mmu.ac.uk/621451/

Version: Accepted Version

Publisher: Taylor \& Francis (Routledge)

DOI: https://doi.org/10.1080/14631180.2018.1495471

Please cite the published version 


\section{Housekeeper, correspondent and confidante: the under-told story of Mrs Hayes of Charlecote Park, 1744-73}

In the summer of 1753, Philippa Hayes wrote from Charlecote Park in Warwickshire to George Lucy in Cheltenham. She informed him that 'Yr cozen Dighton, his Son Frank \& Daughter Bell are come to Dine with me \& sit by whilst I scribble this'. She went on to relate a story about Anne Brown, a friend of Lucy's, whose carriage was overturned by a wagon. Happily, nobody was hurt, but Hayes' letter noted that the angry Mrs Brown had taken the footman's whip and 'strap'd ye Waggoner heartily and when she came home served her own coachman ye same sauce, $\&$ he is run away wth ye livery $\&$ she hath sent a hue $\&$ cry after him'. ${ }^{1}$ There is little that is unusual in either the image of relaxed country house sociability or the violent way in which power relations between mistress and servant were played out. What is striking, however, is that Philippa Hayes was George Lucy's housekeeper. Her socialising with Lucy's relatives, her sharing of stories of misadventure and the abuse of servants, and the nature of her letter writing, all challenge how we view the relationships and roles of senior servants within the life of the English country house.

Histories of the country house have undergone something of a transformation in the last twenty years or so. Alongside the long-standing interest of art and architectural historians, there is a growing body of literature that explores the social history of the country house, much of it taking Mark Girouard's seminal work as a departure point. ${ }^{2}$ This has variously explored the process of building and the impact of empire, consumption and gender on the country house and its owners. ${ }^{3}$ This has involved a gradual shift in emphasis, away from the male owner as the key and often the sole driver of change, and towards a broader perspective that also takes into account the part played by women as owners, wives and daughters. ${ }^{4} \mathrm{~A}$

\footnotetext{
${ }^{1}$ Warwickshire Record Office (WR0), L6/1373, Mrs Hayes to George Lucy, 30 July 1753.

${ }^{2}$ M. Girouard, Life in the English Country House (New Haven, 1978).

${ }^{3}$ See, for example, R. Wilson and A. Mackley, The Building of the English Country House (London , 2000);

R. Baird, Mistress of the House. Great Ladies and Grand Houses, 1670-1830 (London, 2003); S.

Barczewski, Country Houses and the British Empire (Manchester, 2014); J. Stobart and M. Rothery, Consumption and the Country House (Oxford, 2016).

${ }^{4}$ Baird, Mistress of the House; J. Lewis, 'When a house is not a home: elite English women and the eighteenth-century country house', Journal of British Studies, 48 (2009), 336-63; J. Whittle and E. Griffiths, Consumption and Gender in the Early Seventeenth Century Household (Oxford, 2012); B. McDonagh, Elite Women and the Agricultural Landscape, 1700-1830 (London, 2018).
} 
wider social and political role is recognised, but there is particular emphasis on the ways in which women were central to the management of the household - a role that frequently extended to decorating and furnishing the house and managing the estate. ${ }^{5}$ In this, they paralleled the lives of their middling counterparts, who, as Karen Harvey has argued, were often in charge of the day-to-day management of households the oeconomy of which was overseen by the male head. ${ }^{6}$

In contrast, there have been fewer attempts to consider the position of servants, especially for periods before the late nineteenth and early twentieth centuries. ${ }^{7}$ When the spotlight does fall on those in service, it is all too often used to reveal rather simplistic notions of upstairsdownstairs divisions and centres attention on their places of work. ${ }^{8}$ This is understandable, given their crucial role in making the country house function as a comfortable and showy residence, but it means that we know much less about the ways in which servants related to their employers and the wider social role that they played within the house. This is true even for senior servants. Recent work by Carol Beardmore has shone useful light on the place of stewards in the local community, ${ }^{9}$ but there is very little on housekeepers, who did so much to shape the country house milieu and who have often left a much fuller record in terms of account books and correspondence. They are defined by their work, as house managers, guardians and guides, not by their lives, and they are seen as serving the physical rather than social or emotional needs of the owner.

Which brings us back to Mrs Hayes. Some time around 1744, the life-long bachelor, George Lucy (1740-86) engaged her as housekeeper for Charlecote Park, apparently on the

\footnotetext{
${ }^{5}$ See, for example, A. Vickery, Behind Closed Doors. At Home in Georgian Britain (New Haven, 2009); McDonagh, Elite Women and the Agricultural Landscape.

${ }^{6}$ K. Harvey, The Little Republic: Masculinity and Domestic Authority in Eighteenth-Century Britain (Oxford, 2012).

7 The main studies here are still: J. Gerrard, Country House Life: Family and Servants, 1815-1914 (Oxford, 1994); B. Hill, Servants: English Domestics in the Eighteenth Century (Oxford, 1996); P. Sambrook, Keeping their Places: Domestic Service in the Country House (Stroud, 2009); J. Musson, Up and Down Stairs: The History of the Country House Servant (London, 2010). A more focused picture is offered by M. Waterson, The Servants' Hall: a Domestic History of Erddig (London, 1980).

${ }^{8}$ Sambrook, Keeping Their Places, includes some discussion of leisure and personal relationships between servants. Ongoing PhD research on Chatsworth by Hannah Wallace, Fiona Clapperton and Lauren Butler at the University of Sheffield, is attempting to place servants in a broader social and community context.

${ }^{9}$ C. Beardmore, 'The rural community through the eyes of the land agent on the Marquis of Anglesey's Dorset and Somerset estate', unpublished PhD thesis, University of Leicester, 2015. A similar approach is being taken by Hannah Wallace at the University of Sheffield.
} 
recommendation of Lady Anne Coventry, a family friend who lived in the neighbouring village of Snitterfield. ${ }^{10}$ It is unclear how she knew of Philippa Hayes, but it seems that the latter enjoyed good social connections in her native Staffordshire. These included Lady Wrottesley, from whom there are several surviving letters, written in the 1740s. One alludes to a falling out between Mrs Hayes and Lady Wrottesley's father, which may have contributed to her moving south: 'I conclude my papa is now entirely out of yr favour, as I know yr thoughts I shall not endeavour to persuade you he has acted quite a right past'. Moreover, she suggests that a clean break is best: 'I am Entirely of Mr Lucy's opinion, as to what habitation is most proper for you [...] you had therefore best quit yr House at W'hampton, \& by so doing you might stop some of yr friends mouths at ye above mentioned Place'. ${ }^{11}$ It appears, then, that Lucy may have been instrumental in convincing Mrs Hayes to quit Wolverhampton for Warwickshire.

If her path to Charlecote remains obscure, it is very clear that Mrs Hayes was no ordinary housekeeper. She was a respectable widow with grown up children (at least two sons) and thus ideally suited to housekeeping in a large house; but she was able to mix with the local aristocracy in Staffordshire and clearly had good connections elsewhere in the country. Her correspondence with George Lucy and a range of friends and acquaintances reveals much about the position of housekeepers, but layers onto this a series of other roles and relationships which we rarely associate with people employed by others: correspondent, confidante and even hostess. It is her presence in the family archive - through letters and a Household Book - that allows us to reconstruct something of her wider impact on the social and cultural life of Charlecote and thus illuminate the lives of senior servants cum chatelaines in the country house. What I aim to do in this paper, therefore, is to paint a fuller and more detailed picture of one particular life to illustrate the rich experiences and complex roles of such individuals, and to allow them to escape from the strictures of their working lives. In doing so, I challenge the place usually ascribed to women and especially servants: that of supporting role, defined by their formal status in relation to the (male) head of the household.

\section{Housekeeper}

\footnotetext{
10 A. Fairfax-Lucy, Charlecote and the Lucys (London, 1990), 192. The recommendation was endorsed by distant relations in Derbyshire, the Balguys, although how they or Lady Coventry knew of Philippa Hayes remains unclear.
}

11 WRO, L6/1498, Lady Wrottesley to Philippa Hayes, 5 June 1745 
Philippa Hayes was engaged by George Lucy ostensibly as a housekeeper and fulfilled this role with skill and meticulous attention to detail. The full extent of her duties and responsibilities can only be partially reconstructed on the basis of the available evidence, but her role at Charlecote was very evidently wide-ranging and influential. As any good house manager did, she kept a close eye on the linen, china and kitchenware. Her Household Book contains lists of all these that show that she actively managed stocks, noting the condition of goods and any additions being made. ${ }^{12}$ She listed the linen under five headings: 'Linnen belonging to George Lucy Esq', 'For common use', 'Servants Table Linnen \& for Kitchen use', 'Sheets', and 'Sheets for Common use'. Where appropriate, she noted the marking (either F.L. or G.L.) and the numbering of sheets and pillow cases - a careful itemisation which reflects the practices of her contemporary, Elizabeth Shackleton, and the importance of keeping track of valuable assets. ${ }^{13}$ Mrs Hayes also noted where or from whom the linen had been acquired, usually 'at ye door' or, more often, from shopkeepers in local towns or weavers in neighbouring villages. In this way, we can see the stock of linen being regularly refreshed, probably in response to her six-monthly reviews of its condition. These were generally reassuring, as on 4 November 1755 when she 'look'd over all ye linen wn Mr Lucy went to Lisbon - all right'. However, she sometimes noted that items were taken out of the house, as when she looked over the sheets and found everything in order 'except one pair Rich took to Naples', or found that repairs were needed, like the 'pair of Sheets that hath been turn'd \& mended for common use'. ${ }^{14}$

All this was fairly standard practice, but it is quite clear that these records were for her own purposes, not so that she could account for herself to her employer. This differentiated Mrs Hayes from Sir Roger Newdigate's housekeepers, for instance, who had their accounts periodically inspected and settled by their employer. It also distinguished her from some of the wives studied by Amanda Vickery, whose spending was also monitored by their husbands. ${ }^{15}$ The relative freedom from close supervision enjoyed Philippa Hayes might be exceptional, but it demonstrates that not all women were emasculated in this way.

\footnotetext{
12 WRO, L6/1476, Household Book of Mrs Hayes.

13 Vickery, Gentleman's Daughter, 150-51. The linen marked F.L. was probably inherited from Fulke Lucy, George Lucy's predecessor at Charelcote.

14 WRO, L6/1476, Household Book of Mrs Hayes, ff.1, 7, 9.

15 Stobart and Rothery, Consumption and the Country House, 188-9; Vickery, Behind Closed Doors, 113 26.
} 
Much the same can be said of her own checking of fish stocks in the old canal, which are also recorded in her Household Book. This is organised on a credit and debit basis, one page recording fish put in and the other fish taken out, the date of each event being carefully itemised. ${ }^{16}$ The debit page also includes a note of the fisherman, most of whom were men from neighbouring estates, including Sir Charles Morduant, Mr Wright, Mr Dighton, $\mathrm{Mr}$ Clopton, Mr Wise. It seems that Mrs Hayes had some kind of proprietorial claim to the fish; these men certainly had their activities monitored and recorded by the redoubtable housekeeper, and she complained in a letter to George Lucy that the gamekeeper had missed the opportunity to acquire new stock in the spring of $1755 .{ }^{17}$ Her recording of the woodcock killed on the estate took her further out of the domestic sphere and into the realm of estate management. She again noted the date, number of birds shot and name of the huntsmen, the last of these usually being the gamekeeper, although some neighbouring gentlemen also appear. Rather than demonstrating an expanded sphere of control, these were probably recorded as part of the domestic regimen: food for the table or gifts for friends and neighbours. Other than this, she appears to have seen the wider estate as beyond her area of expertise and knowledge, for instance seeking advice on the cost of fawns and the management of the stock of deer. ${ }^{18}$

Within the house, however, Mrs Hayes's remit was very broad. Unsurprisingly, it included the management of servants. When the cook ran off to get married in March 1747, George Lucy wrote saying 'I wd have you Act in what manner you think fit, her behaviour has been such that I think not the least regard ought to be had to her, and was she to be turned out directly, t'would be no matter'. He left it up to Mrs Hayes to determine when to dismiss the cook and how best to find a replacement, noting that 'as for a London Cook, I don't like my entertainments so well, as to induce me to be at that expense'. ${ }^{19}$ This proved no easy matter and it was not until June that she recorded in her Household Book that 'Elizabeth Webster came to be Cook to Mr Lucy'. ${ }^{20}$ The difficulty in finding reliable servants has been much commented upon in the nineteenth century, but was clearly a problem much earlier, as

\footnotetext{
16 WRO, L6/1476, Household Book of Mrs Hayes, ff.16-17.

17 WRO, L6/1374, Mrs Hayes to George Lucy, 24 March 1755.

18 WRO, L6/1371, Mrs Hayes to George Lucy, 12 July 1753.

19 WRO, L6/1422, George Lucy to Philippa Hayes, 28 March 1747

${ }^{20}$ WRO, L6/1476, Household Book of Mrs Hayes, f.20.
} 
Vickery notes with Elizabeth Shackleton. ${ }^{21}$ Tolerating poor behaviour and occasional absence was a price sometimes worth paying in order to retain staff who were otherwise reliable and honest. The list of questions put to Mrs Hayes by Lady Chedworth, when asking for a character reference for Bridget Hall, who was seeking a position with her, is fairly predictable: was she honest, good natured and healthy, did she drink, and why had they parted from her (after fourteen years of service as a housemaid). ${ }^{22}$ As her effective employer, Mrs Hayes was seen as carrying authority to answer these questions.

This authority carried into dealings with tradesmen. Time and again George Lucy entrusted and empowered his housekeeper to make decisions not so much on his behalf as for the benefit of the house and household. Unsurprisingly, this was true of groceries, one of the areas identified by Vickery as lying within the wife's remit; Lucy wrote that she should 'order what you think proper from Thornhill, you are very obliging in consulting me first but as you are the best judge [...] send for what you please'. ${ }^{23}$ However, his reliance on and trust in Mrs Hayes was also apparent when it came to refurbishing rooms in the house - generally seen as lying in the purview of the head of the household, perhaps in consultation with his wife. ${ }^{24}$ Domestic improvement does not appear to have greatly concerned George Lucy who was frequently away from home and expressed himself 'happy to have a good old house' which he would make 'decent and content Myself with that'. ${ }^{25}$ Nonetheless, improvements were made to the house, although there is nothing to support Fair-Lucy's suggestion that Mrs Hayes instigated these in an attempt to revive George Lucy's interest in the house and to spend more time at home. ${ }^{26}$ That said, he was happy to leave things to her, trusting her judgement and her ability to deal with tradesmen. For example, when John Stanbridge was working on the common parlour in 1764, there was clearly a problem with the behaviour of the workmen. Lucy expressed his opinion about how to proceed, but then closed by writing that 'I shall leave all these matters to you to settle as you are upon the spot' ${ }^{27}$ She was

\footnotetext{
21 Vickery, Gentleman's Daughter, 135-42. or whether 'tis a humour'.

${ }^{23}$ WRO, L6/1422, George Lucy to Philippa Hayes, 1 March 1761.

24 Whittle and Griffiths, Consumption and Gender, 203-208.

25 WRO, L6/1422, George Lucy to Philippa Hayes, 14 April 1765.

${ }^{26}$ Fairfax-Lucy, Charlecote and the Lucys, 216.

27 WRO, L6/1422, George Lucy to Philippa Hayes, 11 March 1764
}

22 WRO, L6/1422, Lady Chedworth to Philippa Hayes, 6 May 1758. There was a suspicion that Bridget was too fond of the bottle because Lady Chedworth asked 'whether she drinks - her face and nose being red, 
present and he has not, but she was also trusted to negotiate with the architect and monitor the conduct of the craftsmen.

In some ways, the relationship between George Lucy and Philippa Hayes resembles that between husbands and wives in the middling households examined by Karen Harvey. Husbands had overall responsibility for the household oeconomy whilst wives managed things day to day. ${ }^{28}$ As we have seen, Mrs Hayes sought approval for actions that lay outside the everyday whilst taking wide-ranging responsibility for ensuring that Charlecote was run in an efficient manner. At one level, this shows how gendered divisions of labour within marriage could also operate between employers and servants. There was mutual trust and recognition of the scope and limits of responsibility. However, the relationship went much further than this, Mrs Hayes filling many other roles for her employer. Indeed, she stayed on even after noting in her Household Book that 'Mrs Stokes came to be House-Keeper to $\mathrm{Mr}$ Lucy', so clearly her role at Charlecote went well beyond household management. ${ }^{29}$

\section{Correspondent}

George Lucy and Philippa Hayes enjoyed a regular correspondence with surviving letters running from 1747 to 1766 . They appear to have written to each other at least once a week whilst Lucy was away for the season in London, Cheltenham or Bath, or on longer journeys to Portugal or Italy. Indeed, any pause in the flow of letters brought expressions of concern about the health or good humour of the other correspondent. ${ }^{30}$ The content of these letters naturally varied, but there were common elements to both sides of the correspondence. Both were concerned about their own and each other's health. Lucy in particular appears to have been something of a hypochondriac and gave regular updates on the state of his digestive system (a frequent complaint amongst the well-fed landed gentry), but also any colds and coughs. An abiding and more serious problem was a rheumatic fever that particularly affected his hands, leaving him unable to write at times. It was this that occasioned his trips to Portugal and Italy, hoping for some relief or recovery.

\footnotetext{
${ }^{28}$ Harvey, Little Republic, 99-133. See also Whittle and Griffiths, Consumption and Gender, esp. 26-42. ${ }^{29}$ WRO, L6/1476, Household Book of Mrs Hayes, f.21.

30 See, for example: WRO, L6/1375, Mrs Hayes to George Lucy, 7 April 1755; WRO, L6/1443, George Lucy to Philippa Hayes, 1 November 1757. On the ability of letters to create or alleviate anxieties, see S. Whyman, "Paper visits": the post-Restoration letter as seen through the Verney family archive', in R. Earle (ed.), Epistolary Selves: Letters and Letter-Writers, 1600-1945 (Aldershot, 1999), 21-2.
} 
Besides this, Lucy's letters mostly contain reports from where he was staying, sometimes mixed with more general societal and political news; instructions or enquiries about his estate, and responses to the contents of the letters he received. When in Italy, he wrote about his disappointment with Venice (which was smelly), about seeing the sights in Rome (and being weary of the same), and about the beauty of Naples (tempered by the ostentation and questionable morality of its inhabitants). ${ }^{31}$ These were fairly standard reactions to these cities, repeated in many published and unpublished accounts. ${ }^{32}$ Alongside them, however, Lucy added details of his daily exercise (riding and bathing), his social routine (playing cards) and the weather (too hot and very stormy). This was the kind of personal detail most often reserved for friends and family and went beyond the formulaic travelogues seen in many Tourists' letters. ${ }^{33}$ It is all the more remarkable, then, that these were being written to his housekeeper. Much the same was true of his letters from London or Bath, in which he outlined his daily routine and enumerated the company with whom he dined or played cards. Again, though, these were enlivened with gossip: the Court was so full after the end of mourning for Frederick, Prince of Wales, in March 1752, that 'my Lady Guernsey (after taking true pains in dress) was obliged to return, not being able to get in'. More salaciously, he wrote 'I told you the Duke of M_b_gh would make a settlement on her, which you'd never believe; The fact was True'; there was 'not the least doubt of the Dukes ready Compliance' in paying $£ 400$ p.a., but 'You'll be so good to keep this to yourself, as Mrs W. Wishes it might not be known'. ${ }^{34}$

This was intimate gossip being shared with his housekeeper, who he clearly knew would be familiar with the characters and relationships involved. His letters to Mrs Hayes do not, therefore, fall into any simple category; nor is it easy to read a character type for Mrs Hayes from their correspondence. ${ }^{35}$ Different characters were revealed in different parts of each letter exchanged, not least because most revealed a concern not just with society and self, but

\footnotetext{
${ }^{31}$ WRO, L6/1435, George Lucy to Philippa Hayes, 24 November 1756; WRO, L6/1436, George Lucy to Philippa Hayes, 27 December 1756;WRO, L6/1438, George Lucy to Philippa Hayes, 5 April 1757.

32 R. Sweet, Cities and the Grand Tour. The British in Italy, c.1690-1820 (Cambridge, 2012)

${ }^{33}$ See C. Chard, 'Grand and ghostly tours: the topography of memory', Eighteenth Century Studies, 31 (1997), 101-08; French and Rothery, Man's Estate, 137-84.

${ }^{34}$ WRO, L6/1429, George Lucy to Philippa Hayes, 4 March 1752; WRO, L6/1466, George Lucy to Philippa Hayes, 4 April 1762.

${ }^{35}$ On the link between letter writing and character, see C. Brant, Eighteenth-Century Letters and British Culture (Basingstoke, 2006);
} 
also his estate; he almost always enquired about what was going on at Charlecote, from improvements to the house or the wider estate, to the health and well being of servants and his dogs. His letters thus blended elements of what Susan Whyman calls 'sociable' letters to friends with everyday business matters. ${ }^{36} \mathrm{With}$ the latter, he sometimes provided detailed instructions about what he wanted, but more generally expressed his satisfaction with news of the progress being made or requested detailed instructions about what he should buy: 'you know I'm totally ignorant of all these matters, and if you think proper to employ me, the more explicit you are, the better your commission will be executed' ${ }^{37}$

Much of his discussion of such matters was shaped by what Mrs Hayes wrote in her letters to him and, in this sense, there was a real correspondence between them; their letters might even be seen as a form of conversation, each responding to the other's writing. ${ }^{38}$ She wrote about her health and that of others at Charlecote; work on the estate, including the building of a new bridge or the planting of trees (also noted in her Household Book); troubles with the servants (both illness and bad behaviour), and occasionally sent commissions for Lucy to execute in London. ${ }^{39}$ However, much more space is dedicated to events in Warwickshire society, particularly those involving friends and neighbours. Deaths were noted and accidents lamented; petty quarrels within the parish were laughed at; alarming stories about overturned carriages relayed, and details of wills were forwarded. Above all, though, what Mrs Hayes recounted for her employer were details of people who came to view the house or visits she had made to their neighbours. There was, for instance, a party comprising 'Mr Snell \& his Lady one Mr Upton and Mr Mills came here about 5 a clock in the evening, after they had Walk'd about ye House \& Gardens they desired to goe into ye Park \& to see ye church'. Meeting Dr and Mrs Delany there, they returned to the house and were joined by Mr and Mrs Dewes and Mr Greaves of Mickleton who were trying to catch up with Mr Snell. The party remained until after seven o'clock having been accompanied all this time by Mr Sherwood, the curate of Charlecote who lodged with Mrs Hayes whilst Lucy was away; he was left exhausted and unwell. In an earlier letter, she recounted visits made to friends in Snitterfield,

\footnotetext{
36 Whyman, 'Paper visits', 18.

37 WRO, L6/1471, George Lucy to Philippa Hayes, 17 April 1763.

38 On letters as conversation, see Brant, Eighteenth-Century Letters, 21-22.

39 Fairfax-Lucy, Charlecote and the Lucys, 194.
} 
Loxley and Wellesbourne and of the obligation to Mrs Kendall in calling on her way to Walton Hall. ${ }^{40}$

On occasions, Mrs Hayes apologised for the stream of news, writing that 'you will be tired with reading such a pack of stupid stuffe, but I can't help telling you $\mathrm{w}^{\mathrm{t}} \mathrm{I}$ hear'. In reality, George Lucy valued and enjoyed being kept up to date with the news from Warwickshire, writing 'thank you for your Intelligence as to my Country Affairs'. ${ }^{41}$ It kept him in touch and formed the counterpoint to the gossip and social round that he described in his letters. Both in this sense and in the way that they responded to each other's news, there was a genuine and mutual correspondence or conversation - something rather different from the letters exchanged by stewards and their absent masters, which generally focus more narrowly on estate matters. ${ }^{42}$ Indeed, the letters between Lucy and Hayes read more like the exchanges between siblings. This again thwarts any attempt to categorise letter writers according to character: if her letters were performative, then Hayes was playing the part of housekeeper, friend and confidante. ${ }^{43}$

\section{Confidante}

Kate Smith has written of the power of letter writing in linking together people over space and time, both through the writing on the page and the materiality of the page itself. ${ }^{44}$ Most of the correspondents that she examined were members of the same families, with a strong shared history that underpinned their relationship despite the distances that separated them. Letters served to bridge the spatial divide, representing the relationship in physical form as well as in the news that they brought. The close relationship between Mrs Hayes and her employer is readily apparent from their enjoyment of each other's letters and the openness with which they expressed their own thoughts and feelings. George Lucy almost invariably

${ }^{40}$ WRO, L6/1368, Mrs Hayes to George Lucy, 19 July 1749; WRO, L6/1367, Mrs Hayes to George Lucy, 17 July 1749.

${ }^{41}$ WRO, L6/1374, Mrs Hayes to George Lucy, 24 March 1755; WRO, L6/1422, George Lucy to Mrs Hayes, 28 March 1747.

${ }^{42}$ See, for example, P. Hammond and C. Hammond, Life in an Eighteenth-Century Country House (Stroud, 2012); P.H. McKay and D.N. Hall (eds), Estate letters from the time of John, 2nd Duke of Montagu, 1709-39 (Northampton, 2013).

${ }^{43}$ See Brant, Eighteenth-Century Letters, esp. 24.

${ }^{44}$ K. Smith, 'Imperial Families: women writing home in Georgian Britain', Women's History Review, 24 (2015), 843-60. 
opened his letters with thanks for the one he had received. In part, this reflected the conventions of polite letter writing (something which could be learned and practiced ${ }^{45}$ ), but it went beyond this into an expression of genuine enjoyment, not least because Mrs Hayes was an engaging writer. George Lucy's long-time companion John Dobson - who travelled with him on the continent - wrote commending her 'very long and very entertaining' letter and complimenting the 'Life and Spirit' with which she wrote. This reflects contemporary praise for the naturalness of women's letter writing, yet what Lucy himself enjoyed most was the 'pleasure of conversing with my friends tho at a distance' - a telling phrase which reveals much about how he viewed his relationship with a woman who was engaged as housekeeper. ${ }^{46}$ Moreover, the feeling was mutual, Mrs Hayes gently chiding her employer when his letters were slow in coming and reading them closely for news of his well-being as well as society affairs.

The conversations that they so enjoyed were in part based on the exchange of news and gossip noted discussed earlier. Importantly, though, these were underpinned by a surprising level of candour and by a sharp awareness of each other's character and of their social world. I have already highlighted the prominent place in their letters given to updates on health. Lucy's comment from Naples that 'My bowels (I thank God) have been comfortably easy for most part of the time' is typical of the specific nature of these updates. ${ }^{47} \mathrm{We}$ might dismiss this as the self-obsession of a hypochondriac, but Mrs Hayes was genuinely concerned in her employer's well-being. The impact that this might have on her own health was apparent to others; Dolly, daughter of Sir Charles Morduant, a neighbour in Warwickshire, wrote to Mrs Hayes 'to inquire after your health \& spirits, wch I fear must suffer from hearing but an indifferent account of Mr Lucy who I find has not received much benefit from Bath waters' ${ }^{48}$ Such sensibility spoke of a close emotional relationship rather than simply polite concern for her employer.

More revealing is the way in which Lucy could openly discuss his failings. Rather than express the customary delight in Rome's ancient ruins, he admitted that he had been 'hunting

\footnotetext{
45 Brant, Eighteenth-Century Letters, 33-59.

46 WRO, L6/1481, John Dobson to Mrs Hayes, no date, 1755; WRO, L6/1439, George Lucy to Mrs Hayes, 25 April 1757. On women's natural abilities in letter writing, see Brant, Eighteenth-Century Letters, 18-19 and, more generally, N. Clarke, The Rise and Fall of the Woman of Letters (London, 2004).

47 WRO, L6/1439, George Lucy to Mrs Hayes, 25 April 1757.

48 WRO, L6/1489, Dolly Morduant to Mrs Hayes, 17 April 1755.
} 
virtu, but I had the misfortune not to look into an Old brick Wall as far as Others', a disinterest which he later attributed to the fact that 'I am so little acquainted with past transactions' in Roman history. ${ }^{49}$ This avowed lack of classical education was unusual in a gentleman at this time, being a key element of schooling and polite learning, but is almost worn as a badge of honour. ${ }^{50}$ His addiction to gambling at cards was discussed in a more equivocal manner. Most of his letters from London and Bath discuss his fortunes at the table and, after a run of bad fortune at whist, he wrote in 1747 of his determination 'not to put myself to any difficulties on that account'. ${ }^{51}$ Mrs Hayes offered a diplomatic but frank appraisal, which again spoke of the closeness of their relationship: 'you must take your fate, it is not of so great consequence as ye other, as I am persuaded you know how to set bounds to yr losses'. 52

These were again the kind of exchanges that might be seen between siblings: a brother honestly admitting that he was disinterested in classical culture and a sister gently chiding her errant sibling about his gambling and urging more self control - a key gentlemanly virtue. ${ }^{53}$ Lucy and Hayes shared the same genteel milieu, their common values and norms reflecting both her background and the way in which Lucy viewed and treated her as a social peer. This went further: there was a clear understanding that she knew of the various people mentioned in his gossipy accounts of the company in London or Bath. Sometimes, this was simply a question of rattling off a list of names - those at a dinner or a private card party - but there was usually some assessment made of what was said or how people looked. The latter often hinged on their appearance of healthiness, but Lucy also wrote about having met a handsome or fine young woman. He never seems to have viewed any of these as potential marriage partners; despite pressure from several friends, he resisted the temptations of a married life and spent most of his time in mixed company, often with old friends and neighbours from Warwickshire. For her part, Mrs Hayes could be quite forthright in her assessment of people:

\footnotetext{
49 WRO, L6/1436, George Lucy to Mrs Hayes, 27 December 1756; WRO, L6/1447, George Lucy to Mrs Hayes, 12 April 1758.

50 French and Rothery, Man's Estate, 85-101.

51 WRO, L6/1436, George Lucy to Mrs Hayes, 12 April 1747.

52 WRO, L6/1367, Mrs Hayes to George Lucy, 17 July 1749. Lucy appears to have become more cautious in later life, noting in a letter from Bath that he was refraining from cards because they 'play so deeply that I don't care to meddle' - WRO, L6/1453, George Lucy to Mrs Hayes, 9 February 1760.

53 M. Cohen, “"Manners” make the man: politeness, chivalry and the construction of masculinity', 17501830', Journal of British Studies, 44 (2005), 312-29; French and Rothery, Man's Estate, 56-67.
} 
Mr Vener, with whom she took tea, 'will turn out as great a Coxcomb as an in ye county', whilst Mrs Viney played the harpsichord and sang nicely, but was 'a strange disagreeable woman'. The rector of the neighbouring parish of Hampton Lucy, who pressed her to share a bottle of burgundy, was declined because he was 'rather a little in for it wch is generally the case every night' ${ }^{54}$

There was clearly a great deal of candour and trust between the two: their letters are politely framed, but quite open in their assessment of self and others. The informal and intimate nature of parts of their letters suggests a close and long-standing emotional bond between Lucy and his housekeeper. ${ }^{55}$ Mrs Hayes remained at Charlecote in her old age, when her hand became unsteady making entries in her Household Book shaky and uncertain, and when Mrs Stokes had taken over the everyday duties of a housekeeper. When she died in January 1772 , she made her employer executor of her will and left him her small estate. More personally, she added: 'I also give to George Lucy, out of the great regard I have for him, my cornelian seal, and desire he will accept my buff tabby to cover his easy chair'. ${ }^{56}$ Maxine Berg has written about the bequeathing habits of middling and ordinary women, noting their tendency to gift small personal items such as these, usually to mark close personal bonds. ${ }^{57}$ But they were most often given to female friends and are seen by Berg as a way for women to signal and reinforce, post-mortem, their sisterly networks, and perhaps to pass on a particular object-person relationship to another generation. In this light, the two objects gifted by Mrs Hayes have special significance. Cornelian seals were usually held on a ring; she may have worn hers as an item of jewellery and most likely used it to seal her letters. It was thus a potent symbol of their long epistolary relationship and a reminder to George Lucy of his enjoyment of her letters. The buff tabby - most likely a silk taffeta-like cloth with a watered finish which was generally used in furnishings ${ }^{58}$ - may well have been used to cover her own chair at Charlecote. Passing it on to be used in the same manner would again have encouraged Lucy to have remember his old friend: every time he sat in his easy chair, he

${ }^{54}$ WRO, L6/1371, Mrs Hayes to George Lucy, 12 July 1753; WRO, L6/1369, Mrs Hayes to George Lucy, 24 July 1749

55 Whyman, 'Paper visits', 18.

${ }^{56}$ Fairfax-Lucy, Charlecote and the Lucys, 221.

${ }^{57}$ M. Berg, 'Women's consumption and the industrial classes of eighteenth-century England', Journal of Social History, 30 (1996), 415-34.

${ }^{58}$ C. Edwards, Encyclopedia of Furnishing Textiles, Floorcoverings and Home Furnishing Practices, 1200 1950 (Aldershot, 2007), 204-05. 
would have come into contact with her cloth and perhaps with memories of her. Through everyday material objects that were loaded with personal associations, Mrs Hayes thus offered George Lucy ways of remembering their friendship in much the same way that Sarah Churchill recalled past relationships through a range of material objects. ${ }^{59}$

\section{Hostess}

There was mutuality in the confidences placed by Lucy and Hayes. He offered a window onto a world that, whilst by no means closed to her, was not readily accessible. She received news of London and Bath from a variety of sources besides her employer, but there is nothing to suggest that she travelled to these places, although she did visit Derbyshire and several Midlands towns - journeys away from home that are unusual for housekeepers. In general, though Mrs Hayes acted as Lucy's representative in Warwickshire, keeping him abreast of local political developments and maintaining his social networks, which often overlapped with her own. ${ }^{60}$ Amongst other things, he thanked her for the accounts she sent of the entertainments at Warwick Castle associated with the election in 1761 and of the assizes in spring $1765 .{ }^{61}$ These were diverting, but also useful to Lucy in checking the current state of county politics. More importantly, perhaps, they show Mrs Hayes moving in the public sphere - well beyond the confines of the domestic and social. Historians have moved beyond simplistic notions of separate spheres and there is plenty of evidence that eighteenth-century women were involved in public life, including politics. ${ }^{62}$ Nonetheless, it is striking that Mrs Hayes was sufficiently in the public sphere to send reports that were informed and astute. She was independent on the basis of her widowhood, but still in a position of dependence in terms of her employment by Lucy; yet she could clearly mix in and comprehend an ostensibly male world. This underlines the way that notions of dependence and independence were socially contingent as well as gendered.

\footnotetext{
${ }^{59}$ Lewis, 'When a house is not a home'.

60 In this, her actions mirrored those of Margaret Clive, who kept alive her husband's social and political networks when Robert was abroad. Smith, 'Imperial families', 853.

61 WRO, L6/1462, George Lucy to Mrs Hayes, 5 April 1761; WRO, L6/1474, George Lucy to Mrs Hayes, 21 April 1765.

62 See, for example, Vickery, Gentleman's Daughter, 225-84; Baird, Mistress of the House, esp. 100-117, 147-68; A. Shepard, 'Minding their own business: married women and credit in early eighteenth-century London', Transactions of the Royal Historical Society, 25 (2015), 53-74.
} 
What gave Mrs Hayes status was partly her connection with George Lucy; his local standing rubbed off on her and gave her access to the county gentry, both as visitor and hostess at Charlecote. However, she had status and kudos in local society in her own right. When declining an invitation to visit in 1747, Lady Coventry addressed her reply to Mrs Hayes, not George Lucy; she wrote that 'tis no small mortification to me that I shall not see you and $\mathrm{Mr}$ Lucy' - both were clearly an attraction for their titled neighbour. ${ }^{63}$ This is typical of numerous instances where Mrs Hayes was the focus of a visit, not her employer: guests did not stop coming to Charlecote when Lucy was away. As we saw at the start of this paper, she was joined by Lucy's cousin and his children in July 1753; they sat while she wrote part of her letter then spent the rest of the evening playing whist. This questions an older view of letter writing as a solitary and introspective activity. Indeed, it is evident that this particular letter was, in part, the product of several voices. ${ }^{64}$ A post-script reveals that young Frank was pestering Mrs Hayes that she should write to Lucy because 'he would have you look out for a Wife at Cheltenham'. ${ }^{65}$ Even if this was a jest, it telling that the relationships between the Dightons and Mrs Hayes, and between Hayes and Lucy, were close enough to feel that such a request would carry weight or the joke would be well received.

Mrs Hayes was willing and able to act as hostess, receiving a regular stream of guests at Charlectote. Housekeepers often showed around visitors and could sometimes be extremely proprietorial about "their" house. Indeed, it is telling that Thomas Barber's portrait of Mrs Garnett, Lord Scarsdale's housekeeper at Kedleston Hall, shows her with a guidebook in her hand, ready to receive visitors. ${ }^{66}$ But with Philippa Hayes, this went further: it was guests rather than simply visitors who came to Charlecote and she evidently felt herself worthy of notice and part of the network of polite visiting that enmeshed society in the countryside as well as town. It was a slight, therefore, when people chose not to call at "her" house. In July 1749 'Squire Chester \& his Lady pas'd by ye stable gates in their way to Knowl but did not doe us ye favour to send in wch was rather over looking us'. Her addendum, 'but we must be content', suggests the reverse. She was also less than happy when visits were too brief to accord with a sense of civility and the norms of polite visiting, perhaps because this undermined her sense of self-worth. Such was the case when Mr Palmer 'call'd here \& staid I

\footnotetext{
63 WRO, L6/1478, Lady Anne Coventry to Mrs Hayes, 4 September 1747.

${ }^{64}$ R. Earle, Epistolary Selves: Letters and Letter-Writers, 1600-1945 (Aldershot, 1999), 6-8. 65 WRO, L6/1373, Mrs Hayes to George Lucy, 30 July 1753.

${ }^{66}$ A. Tinniswood, The Polite Tourist, Four Centuries of Country House Visiting (New York, 1999), 108.
} 
believe a full minitt'; he compounded his error when he visited the next day in the company of the young Charles Morduant and 'staid about a minit \& half'. ${ }^{67}$ Such brief stays not only meant that the conventions of entertaining were curtailed (there was no chance to serve tea or chocolate, or engage in conversation), they also implied that the hostess was not important enough to merit a longer visit.

If she had a high opinion of her own worth, then this was shared by many others. George Lucy frequently passed on the kind wishes of mutual friends he met with and there were regular enquiries after her health. These start in the earliest surviving letter from Lucy to Hayes, a post script to which read 'I had like to have forgot Lady Wrottesley enquired very kindly after you', and they continue through their correspondence. Unlike the mixed company that Mrs Hayes entertained at Charlecote, this was an essentially female circle of well wishers that included Lady Coventry, Mrs Wright, Miss Parker, Mrs Lane and Mrs Kendall, though 'Mr Granville always charges me with his Compts to you' ${ }^{68}$ Similarly, her surviving correspondence, other than that with George Lucy, was predominantly with other women and she was a particular confidante of Dolly Morduant. Their letters included discussion of various new books and plays, revealing another important aspect of Mrs Hayes's multifaceted character: that of avid reader or, as Dolly put it, 'a great Book worm'. ${ }^{69}$ Hayes bought and borrowed books from Samuel Clay's bookshop in Warwick, including several printed plays that had first been performed just a few months earlier in London. ${ }^{70}$ This suggests a large degree of control over her own time and a good measure of personal mobility - being able to travel the six miles or so into Warwick on a fairly regular basis. It also demonstrates an awareness of the latest publications and the London theatre scene, both of which she may have accessed from the newspapers or via her correspondents, although only two letters from Dolly Morduant allude to this.

Mrs Hayes was clearly a well-read and well-connected woman, arguably part of a female republic of letters. ${ }^{71}$ However, as we have already seen, hers was far from a purely female

\footnotetext{
67 WRO, L6/1367, Mrs Hayes to George Lucy, 17 July 1749; WRO, L6/1371, Mrs Hayes to George Lucy, 12 July 1753.

68 WRO, L6/1422, George Lucy to Mrs Hayles, 28 March 1747; WRO, L6/1422, George Lucy to Mrs Hayles, 17 April 1763.

${ }^{69}$ WRO, L6/1487, Miss Dolly Morduant to Mrs Hayes, 3 April 1755.

70 J. Fergus, Provincial Readers in Eighteenth-Century England (Oxford, 2006), 93.

${ }^{71}$ See, for example, S. Dalton, Engendering the Republic of Letters: Reconnecting Public and Private Spheres (Montreal, 2003); A.R. Larson, 'A Women's Republic of Letters: Anna Maria van Schurman, Marie de
} 
world and she was also in correspondence with John and Charles Dobson, C Egerton, Sir Charles Morduant, and the architect-builder William Smith. The last of these hints at her role in shaping the improvements being made at Charlecote, which in some ways put her in the role of surrogate wife: it was as much her house as Lucy's and, although the ultimate authority lay with him, the ways in which key rooms were decorated reflected her judgement and taste. Beyond the things that she bequeathed, it is hard to know whether she had the sort of emotional attachment to objects that is seen in the women studied by Judith Lewis. It seems unlikely, given her lack of family connection with the house, and there is nothing to suggest it in her letters. However she did play a significant role in mediating the designs of John Stanbridge and appears to have been visited on several occasions in mid 1760s by the architect Timothy Lightholer, lately engaged on improvements being made at Stoneleigh Abbey, some ten miles north of Charlecote, by Edward, fifth Lord Leigh. ${ }^{72}$ George Lucy could joke that 'Mr Lightholder does you great $\operatorname{Hon}^{\mathrm{r}}$ in his frequent visits, perhaps the want of Employment, rather than Curiosity, may be the principal motive' ${ }^{73}$ Intentionally or not, he makes clear that Lightholer was visiting Mrs Hayes, not him; regardless of his prime motive, it was through the housekeeper that he saw the opportunity to gain commissions for work.

\section{Conclusions}

Mrs Hayes was far from being an ordinary housekeeper; she was far more like an unmarried or widowed sister, brought in to keep house for a bachelor brother. ${ }^{74}$ But even in this light, she was remarkable, enjoying power and status in her role at Charlecote - far more than that experienced by some of the elite wives studied by Vickery, whose spending was subjected to close scrutiny and bounded by closely drawn gender roles. ${ }^{75}$ In part due to the frequent and lengthy absence of her employer, she enjoyed considerable trust and played an important part in shaping improvements to the house. More importantly, she was central in maintaining

Gournay, and Female Self-Representation in Relation to the Public Sphere', Early Modern Women, 3 (2008), 105-26; C. Pal, Republic of Women: Rethinking the Republic of Letters in the Seventeenth Century (Cambridge, 2012).

${ }^{72}$ A. Gomme, 'Abbey in to palace: a lesser Wilton?', in R. Bearman (ed.), Stoneleigh Abbey. The House, Its Owners, Its Lands (Stratford-upon-Avon, 2004), 101-05.

${ }^{73}$ WRO, L6/1475, George Lucy to Mrs Hayes, 6 March 1766.

${ }^{74}$ See A. Duncan, 'Olds maids: family and social relationships of never-married Scottish gentlewomen, c.1740-1840', (unpublished PhD thesis, University of Edinburgh, 2013), esp. 57-87.

75 Vickery, Behind Closed Doors, 113-26. 
Lucy's social connections in the county, exchanging visits and letters with relatives and neighbours. However, she also enjoyed status in her own right: her letters were enjoyed, her well-being enquired after, her company sought out, and her opinions valued. In this, her status was important, but so too were her personal qualities. Combined with her loyalty, these made her a confidante and friend, someone who shared a close emotional bond with George Lucy. She remained at Charlecote in her old age: a friend to be cared for rather than a servant to be tasked with work.

From this discussion, a more general issue arises: that of the role of women and particularly housekeepers in shaping the country house. Women's impact on the material culture of the house is sometimes difficult to discern and thus assumed to be modest. None of the improvements made to the inside of the house at Charlecote were particularly profound, especially in comparison with the later alterations of George Hammond Lucy. ${ }^{76}$ Moreover, it is impossible to know exactly whose taste informed final decisions, though Mrs Hayes undoubtedly played an important part. This was frequently the case with wives, as is increasingly being recognised; but it not normally part of the housekeeper's role: stewards might liaise with builders and tradesmen and thus in some small measure shape the process and the outcome of any improvements. ${ }^{77}$ Yet Mrs Hayes shows that this role could also stretch to the housekeeper. Less eye catching, but arguably more important, is their role in running the house, harbouring resources, overseeing servants, and the like. This is the fate that historians, including Vickery and Harvey, have seen as being allotted to women; they were managers of the household oeconomy. It is too easy to overlook the ways in which this empowered women - Alice le Strange, for instance, was the undoubted ruler of her household and Mrs Hayes appears to have enjoyed a similar level of independence. ${ }^{78}$

Without belittling these material achievements, Mrs Hayes - and arguably elite women more generally - had a more profound impact in maintaining the household's social capital. This worked at many different levels. Most obvious was her role in keeping up the social life of the country house and its place within a broader network of sociability and mutual obligation and regard. Visits and letters were the lubricant in this process, oiling the wheels that kept

\footnotetext{
${ }^{76}$ George Hammond Lucy's alterations are discussed in C. Wainwright, The Romantic Interior: the British Collector at Home, 1750-1850 (New Haven, 1989).

77 Stobart and Rothery, Consumption and the Country House, 187-94.

78 Whittle and Griffiths, Gender and Consumption.
} 
county society running smoothly between the periodic public events. ${ }^{79}$ Mrs Hayes mostly interacted with members of the county gentry, but also corresponded other housekeepers, thus articulating both elite and plebeian networks. Just as important, but less immediately obvious, is the way which women like Mrs Hayes offered pleasure and comfort through their company and their correspondence. Their society made country living enjoyable and their letters created a bridge to home when far away. As George Lucy put it: 'Your letters always give me great pleasure $[\ldots]$ be assured I shall always be glad to hear from you' ${ }^{80}$

79 Smith, 'Imperial families', 853; Vickery, Gentleman's Daughter, 205-09; Vickery, Behind Closed Doors, 274-5, 294-5.

80 WRO, L6/1437, George Lucy to Mrs Hayes, 22 March 1757. 